\title{
Angiogenesis Versus Antiangiogenesis in Colorectal Cancer Patients with and Without Liver Metastases
}

\author{
Aisha S. Eid*, Moustafa A. EL-Shazli**,Alia A. Ayad*** \\ and Eman M. Zaki\# \\ Departments of Medical Biochemistr*, Surgery**, \\ Internal Medicine*** and Radiology\# Faculty of Medicine and \\ National Cancer Institute\#, Cairo University.
}

\begin{abstract}
Angiogenesis is essential for tumor growth and progression and is mediated by positive and negative regulators of vessel growth. Since angiogenic mediators found in patient's serum have been postulated to reflect the angiogenic potential of a malignant tumor, the angiogenic stimulators activity such as vascular endothelial growth factor (VEGF) and angiogenesis inhibitors such as endostatin have been evaluated in the serum of patients with colorectal caner (CRC) with and without liver metastases, in an attempt to study the prognostic value of the above parameters. The present work was conducted on thirty six patients with colorectal cancer and twelve control subjects. The patients' group included twenty localized colorectal cancer patients all of them had radical surgical resection. The second patients' group consisted of sixteen colorectal cancer patients with liver metastases. The serum endostatin and VEGF levels were significantly higher in the patients with colorectal cancer versus healthy controls. When compared according to tumor stage, the liver metastatic group had significantly higher levels of serum endostatin and VEGF versus the localized invasive group (without distant metastasis). Both groups of patients with localized invasive cancer and patients with liver metastasis had significantly higher mean serum endostatin and VEGF levels versus healthy controls. Serum endostatin and VEGF levels in localized invasive group decreased significantly after resection of the tumor. There was a significant positive correlation between preoperative endostatin and VEGF levels in all cancer patients. High preoperative VEGF and endostatin levels were strongly associated with the tumor size, tumor grade, lymph node metastases and subsequent recurrence. Significant positive correlation was, also, detected between endostatin levels and number as well as volume of hepatic metastases.The previous results denote that serum levels of endostatin, and VEGF were elevated and positively correlated in patients with CRC. The elevation was associated with the stage of CRC, greater disease burden and subsequent recurrence. Thus, elevation of serum levels of endostatin, and VEGF might be considered as indicators of tumor invasion and metastasis in the future. Thus, the present study demonstrates the prognostic utility of measuring angiogenic and antiangiogenic factors before resection of colorectal cancer.
\end{abstract}

Key words: colorectal caner (CRC), vascular endothelial growth factor (VEGF), endostatin, liver metastases. 


\section{INTRODUCTION}

Colorectal cancer (CRC) is the third most common malignancy in western countries ${ }^{(\mathbf{1})}$. Of all patients affected by CRC, 75\% undergo surgical treatment with curative intent; however, at present, $50 \%$ of these patients die within 5 years, mostly due to recurrence of disease ${ }^{(1)}$. Liver metastases occurs in approximately $45 \%$ of patients at some point in their disease course. Although some patients have favorable outcomes after liver resection, alternative therapeutic options are needed to treat patients whose tumors recur after resection, as well as those with unresectable disease $^{(2)}$.

Angiogenesis is the formation of new capillaries from the preexisting blood vessels. Angiogenesis is critical for tumor growth and metastasis. The concept of tumor angiogenesis originally stemmed from Folkman's innovative proposition that tumor growth beyond a few millimeters is dependent on the formation of new blood vessels from neighbouring tissue $^{(3)}$. Angiogenesis is regulated by complex signaling pathways acting on endothelial cells that stimulate cell proliferation, migration, and subsequent tube formation ${ }^{(3,4)}$. The level of angiogenic activity within a tissue is determined by the balance between stimulatory and inhibitory molecular regulators of endothelial cell activation. As tumors progress, they must acquire the ability to switch from a physiologically inhibitory environment to one that promotes new blood vessel development ${ }^{(5,6)}$.

Neovascularization is a prerequisite for tumor growth ${ }^{(4)}$.
Several studies indicated that angiogenesis plays a pivotal role in the prognosis of many types of cancer ${ }^{(7)}$. It has been reported that tumor angiogenesis may be triggered after an increase (up-regulation) in the level of angiogenic stimulators such as vascular endothelial growth factor (VEGF), matrix metalloproteinases (MMPs) as well as basic fibroblast growth factor (bFGF), and a concomitant decrease (downregulation) in the levels of endogenous angiogenesis inhibitors (e.g. thrombospondin-1) ${ }^{(8)}$.

The vascular endothelial growth factor (VEGF), a potent mitogen for endothelial cells, is the most important factor in the neoplastic angiogenesis. VEGF is a homodimeric, 34- to 42-kDa heparinbinding glycoprotein with mitogenic and vascular permeability-enhancing activities for endothelial cells ${ }^{(7)}$. Its activity is mediated by two highaffinity tyrosine-kinase receptors, fms-like tyrosine kinase (flt-1) and fetal liver kinase-1 (flk-1): flk-1 is a major regulator of angiogenesis, both in vitro and in vivo ${ }^{(7)}$. It is thought that VEGF is the most important angiogenic factor closely associated with induction and maintenance of the neovasculature in human tumors. Burns et al., ${ }^{(8)}$ suggested that VEGF may prevent tumor cell apoptosis via the bcl-2 anti-apoptotic pathway. The increased expression of VEGF mRNA has been detected in a variety of tumors, and recently tumor VEGF level was hypothesized as an important prognostic marker of tumor angiogenesis $^{(\mathbf{9 , 1 0})}$.

One of the first antiangiogenesis compounds to be proposed and 
evaluated for treatment of patients with cancer was endostatin. Endostatin is an endogenous angiogenic inhibitor, isolated from hemangioendothelioma cells as a $\mathrm{COOH}$-terminal segment of collagen $\mathrm{XVIII}^{(\mathbf{1 1 , 1 2})}$. On the cellular level, endostatin has been shown specifically to block proliferation and migration of endothelial cells and to induce endothelial cell apoptosis ${ }^{(13,14)}$. Elucidation of the detailed mechanisms by which endostatin affects tumor dormancy and angiogenesis is now under intense investigation $^{(15)}$.

The critical role of angiogenesis in $\mathrm{CRC}$ progression was previously reported but is yet under intense investigation. The present study aimed to clarify the balance between angiogenic and antiangiogenic factors by analyzing the serum concentrations of VEGF, as representative of angiogenic factors, and that of endostatin, as the antiangiogenic factor, in normal subjects and in patients with CRC with and without metastases in an attempt to study the prognostic value of the above parameters.

\section{SUBJECTS \& METHODS}

The present work was conducted on thirty six patients with pathologically confirmed colorectal adenocarcinoma. They were among the patients attending the National Cancer Institute, Hepatosurgery Unit and Hepatogastroenterology Outpatient Clinic in Kasr El Aini Hospital. Informed consent was obtained for all patients. Their ages ranged from 36 to 72 years. In addition, twelve normal healthy subjects of matched age and sex were included as control group. Demographic data for the healthy controls were recorded at time of blood collection.

Clinical information regarding patients was obtained from medical records. These patients were evaluated clinically. No patient had an active infection or inflammatory bowel disease at the time of study or had received a blood transfusion, radiotherapy, or chemotherapy before the study. According to the presence or absence of liver metastases patients were classified into 2 subgroups: The first patient's group included twenty localized colorectal cancer patients, all of them had radical surgical resection. Patients were considered to have undergone radical resections when there were no metastases detected by preoperative radiological scans (ultrasound scan, chest $\mathrm{x}$ ray,magnetic resonance imaging, or computed tomographic scan) and intraoperative ultrasound scan of the liver. Details of the primary colorectal cancer and treatment were recorded, and it included site, tumor node metastases, stage and surgical treatment.

Clinical characteristics for the twenty patients are summarized in (Table: 1).

The second patient's group consisted of sixteen colorectal cancer patients with liver metastases for possible surgical treatment. Preoperative helical computed tomography images (HiSpeed Advantage or Light Speed; GE Medical Systems, Milwaukee, WI) were analyzed, and the greatest perpendicular diameter of each 
hepatic lesion was measured. Measurements were independently audited by a radiologist blinded to plasma cytokine levels. Tumor volumes were calculated with the formula $4 / 3 r^{3}$, where $r$ represents the mean radius of the two measurements taken. Hepatic tumor burden in each patient was calculated by adding the volumes of individual hepatic tumors.

Clinical characteristics for the sixteen patients are summarized in (Table: 2 ).

The tumor grade and tumor stage were determined according to the TNM system ${ }^{(\mathbf{1 6})}$ and World Health Organization $\quad$ classification $^{(17)}$, respectively. The tumors were thus classified according to grade of the tumor into:

- T1: tumor invading the lamina propria or mucosa.

- T2: tumor invading the muscularis or submucosa.

- T3: tumor penetrating the serosa or invading adjacent organs.

And according to stage of the tumor into:

- Stage I: No lymph node involvement and no distant metastases

- Stage II: 1-3 lymph nodes involved and no distant metastases

- Stage III: 4 or more lymph nodes involved and no distant metastases

- Stage IV: any number of lymph nodes involved with presence of distant metastases.

After a follow-up of 12 months, $5(25 \%)$ of the assessable 20 patients (who had CRC without liver metastases) had disease recurrence, and one of these 5 patients died of disease. Sites of recurrence included one rectal recurrence, one liver recurrence, one lung recurrence and one multifocal recurrence.

Blood samples were obtained from patients, before surgery and during follow-up visits, and from ageand sex-matched volunteer blood donors (controls). Blood samples were drawn from all participants (all patients and controls) after an overnight fast before and at seventh day after resection of the tumor for the estimation of serum levels of VEGF $^{(\mathbf{1 8})}$, and endostatin ${ }^{(\mathbf{1 9})}$. Blood samples were centrifuged at $3000 \mathrm{rpm}$ for $20 \mathrm{~min}$. after being allowed to clot at room temperature. Sera were separated after centrifugation, then aliquoted and stored at $-80{ }^{\circ} \mathrm{C}$ until the assays were performed. The above parameters were determined by the sandwich enzyme immunoassay technique using kits supplied by Quantikine, R\&D System,Inc. Minneapolis, USA .

Statistical analysis:

Data are represented as mean \pm SD. For comparison of the means of 2 groups, unpaired t-test is used. Cytokine levels $>2$ S.D. above the control mean were considered elevated. Mean values of variables were compared using analysis of variance (ANOVA) followed by posthoc test. The Pearson and Spearman correlation tests were used to assess the correlation between the variables. $P$ values $<0.05$ were considered statistically significant. ${ }^{(20)}$

\section{RESULTS}

The results of the present study are presented in tables 1-9 and figures 15. 
Table 1: Clinical characteristics of patients with localized colorectal carcinoma $(\mathbf{n}=\mathbf{2 0})$.

\begin{tabular}{|c|c|c|}
\hline Variable & Number & $\%$ \\
\hline Age (year) & & \\
\hline Mean & 53.5 & \\
\hline Range & $34-84$ & \\
\hline$\underline{\operatorname{Sex}}, \mathrm{n}(\%)$ & & \\
\hline Male & 11 & $55 \%$ \\
\hline Female & 9 & $45 \%$ \\
\hline$\underline{\text { Tumor size }}(\mathrm{cm})$ & & \\
\hline Mean & 4.28 & \\
\hline Range & $1-6.8$ & \\
\hline Tumor grade* ${ }^{*}, \mathrm{n}(\%)$ & & \\
\hline $\mathrm{T} 1$ & --- & \\
\hline $\mathrm{T} 2$ & 10 & $50 \%$ \\
\hline $\mathrm{T} 3$ & 10 & $50 \%$ \\
\hline Lymph node metastasis, n (\%) & & \\
\hline Stage I (no lymph node involvement) & 8 & $40 \%$ \\
\hline Stage II, III (presence of lymph node involvement) & 12 & $60 \%$ \\
\hline
\end{tabular}

*T1: invading the lamina propria or mucosa.

T2: invading the muscularis or submucosa.

T3: penetrating the serosa or invading adjacent organs.

Table 2: Clinical characteristics of patients with colorectal carcinoma with liver metastases $(n=16)$.

\begin{tabular}{l|c|c}
\hline Variable & Number & $\%$ \\
\hline Age (year) & 58.5 & \\
Mean & $28-81$ & \\
Range & & \\
Sex, n (\%) & 10 & $63 \%$ \\
Male & 6 & $37 \%$ \\
Female & & \\
Number of hepatic metastases & 9 & $56 \%$ \\
$\quad \leq 5$ & 7 & $44 \%$ \\
$>5$ & & \\
Hepatic tumor volume (mL) & 11 & $69 \%$ \\
$\quad \leq 300$ & 5 & $31 \%$ \\
$>300$ & & \\
\hline
\end{tabular}


Table 3: Serum levels of VEGF and endostatin in patients with colorectal cancer and healthy controls.

\begin{tabular}{l|ccc}
\hline & $\begin{array}{c}\text { Controls } \\
(\mathbf{1 2} \text { cases) }\end{array}$ & $\begin{array}{c}\text { All patients } \\
\text { (36 cases) }\end{array}$ & P- value \\
\hline VEGF $(\mathrm{pg} / \mathrm{mL})$ & $88.8 \pm 32.9$ & $423.5 \pm 156.8$ & $<0.001$ \\
Endostatin(ng/mL) & $26.4 \pm 9.1$ & $64.4 \pm 15.5$ & $<0.001$ \\
\hline * Values are expressed as mean $\pm S D$. & & \\
$*$ VEGF: Vascular endothelial growth factor. & & \\
$* P<0.05:$ significant.
\end{tabular}

The serum endostatin and VEGF levels were significantly higher in the patients with colorectal cancer versus healthy controls $(\mathrm{P}<0.001)$ (Table 3$)$.

Table 4: Serum levels of VEGF and endostatin in patients with colorectal cancer (CRC) and frequencies of their elevation according to tumor stage.

\begin{tabular}{l|cccc}
\hline & $\begin{array}{c}\text { Controls } \\
\text { (12 cases) }\end{array}$ & $\begin{array}{c}\text { Localized CRC } \\
\text { (20 cases) }\end{array}$ & $\begin{array}{c}\text { Metastatic CRC } \\
\text { (16 cases) }\end{array}$ & P- value \\
\hline VEGF (pg/mL) & $88.8 \pm 32.9(\mathrm{a})$ & $366.7 \pm 150.6(\mathrm{~b})$ & $494.3 \pm 143.7(\mathrm{c})$ & $<0.001$ \\
Endostatin $(\mathrm{ng} / \mathrm{mL})$ & $26.4 \pm 9.1(\mathrm{a})$ & $58.9 \pm 14.8(\mathrm{~b})$ & $71.1 \pm 14.5(\mathrm{c})$ & $<0.001$ \\
\hline
\end{tabular}

$*$ Values are expressed as mean $\pm S D$.

* VEGF: Vascular endothelial growth factor .

* Localized group: patients with localized invasion ; Metastatic group: patients with distant metastasis

* Similar letters $(a, b, c)$ indicate non-significant differences between groups. Difference in letters indicates significant differences.

When compared according to tumor stage, the liver metastatic group had significantly higher levels of serum endostatin and VEGF versus the localized invasive group (without distant metastasis). Both two subgroups of patients with localized invasive cancer and patients with liver metastasis had significantly higher mean serum endostatin and VEGF levels versus healthy controls (Table 4).

Table 5: Serum levels of VEGF and endostatin in patients with localized colorectal cancer before and after resection of the primary tumor.

\begin{tabular}{l|ccc}
\hline & Before resection & After resection & P-value \\
\hline VEGF $(\mathrm{pg} / \mathrm{mL})$ & $366.7 \pm 150.6$ & $251.52 \pm 102.6$ & $<0.001$ \\
Endostatin $(\mathrm{ng} / \mathrm{mL})$ & $58.9 \pm 14.8$ & $47.5 \pm 11.4$ & $<0.001$ \\
\hline
\end{tabular}

* Values are expressed as mean $\pm S D$.

*VEGF: Vascular endothelial growth factor.

* $P<0.05$ : significant. 


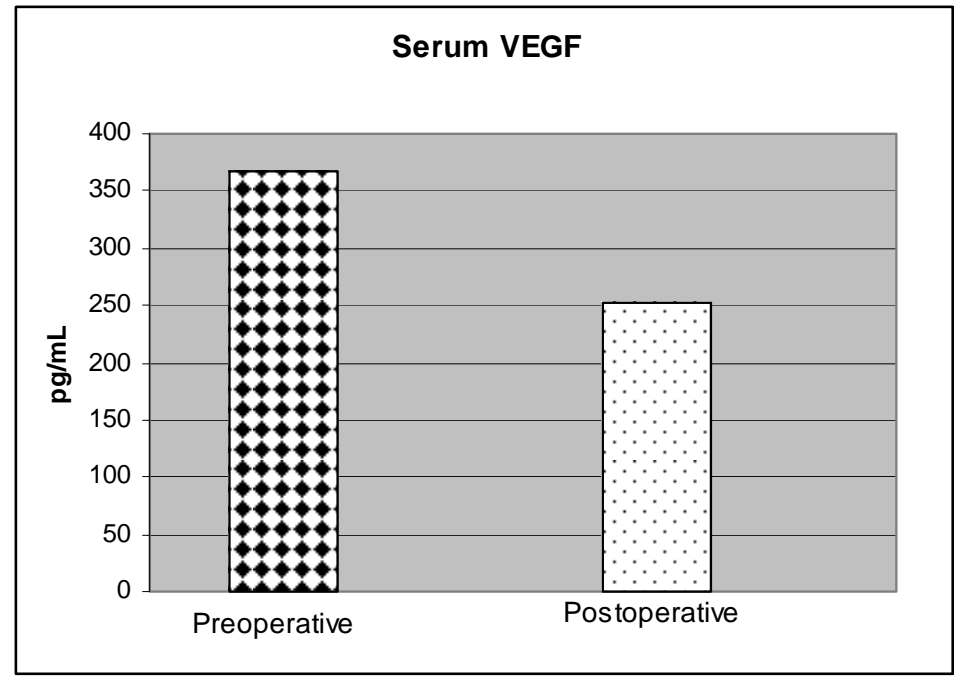

Fig. 1: Pre- and postoperative serum VEGF in patients with localized CRC.

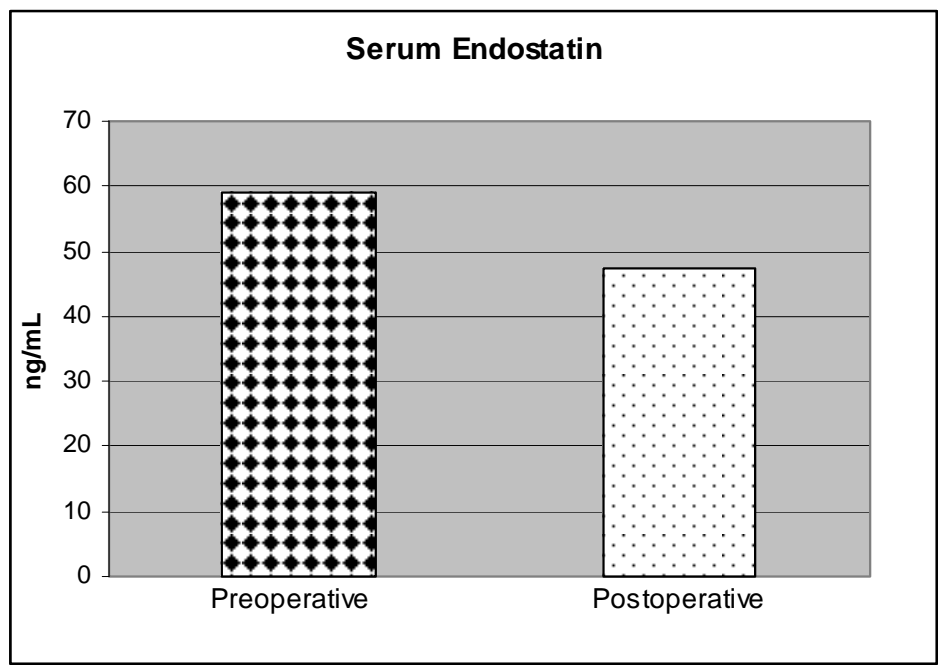

Fig. 2: Pre- and postoperative serum Endostatin in patients with localized CRC. 
Serum endostatin and VEGF levels in localized invasive group decrease significantly after resection of the primary tumor (Table 5) and (Figures 1 and 2).

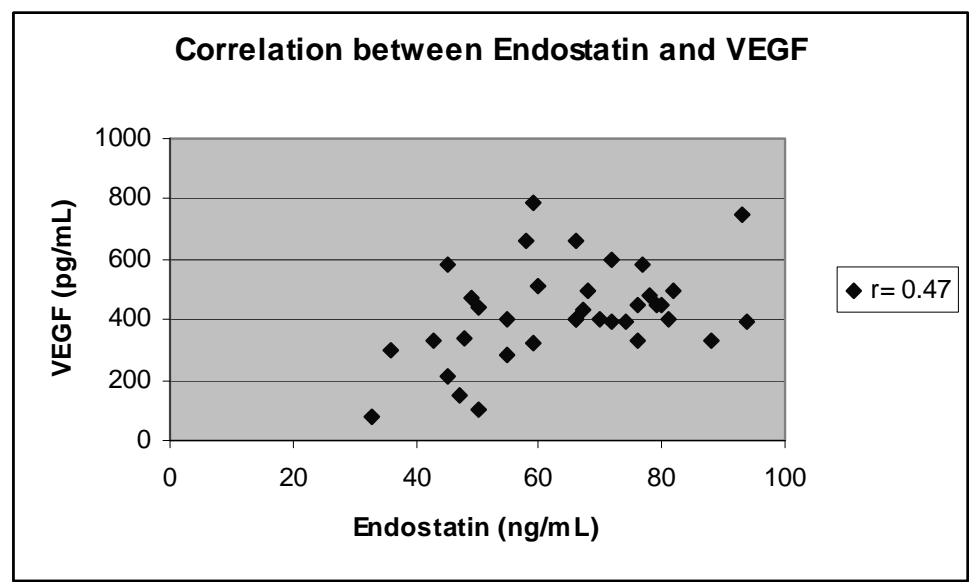

Fig. 3: Scatter plot showing the correlation between preoperative serum endostatin and preoperative serum VEGF in localized CRC patients.

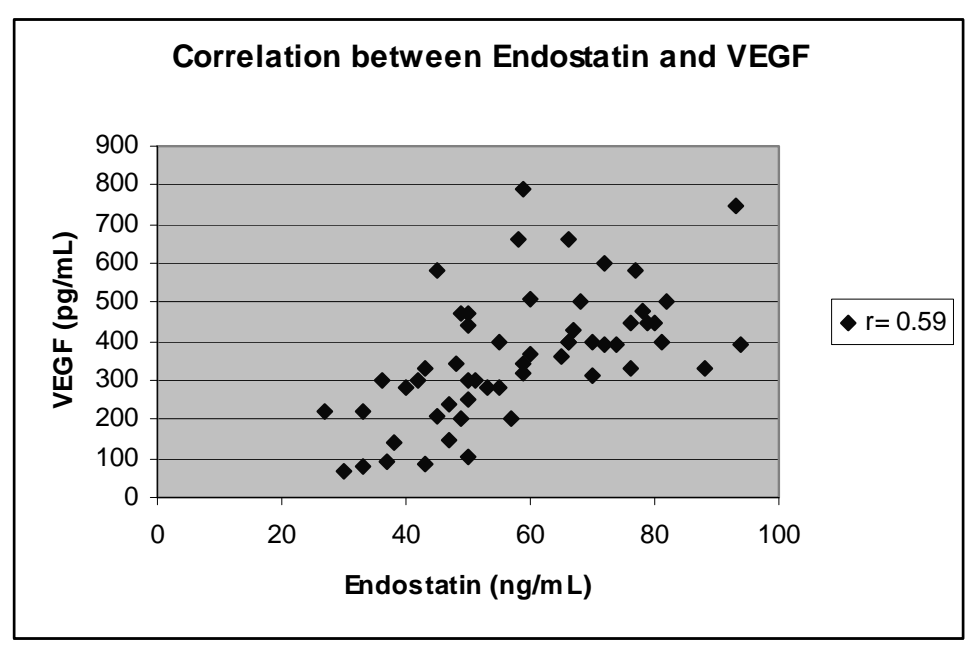

Fig. 4: Scatter plot showing the correlation between serum endostatin and VEGF in all CRC patients. 
There was a significant positive correlation between preoperative endostatin and VEGF in localized CRC patients $(r=0.47)$, and between endostatin and VEGF levels in all cancer patients $(\mathrm{r}=0.59 \mathrm{P}<0.001)$
(Fig. 3, 4). This correlation was absent in controls. There was no significant correlation between preoperative endostatin and VEGF levels and age and no association with sex.

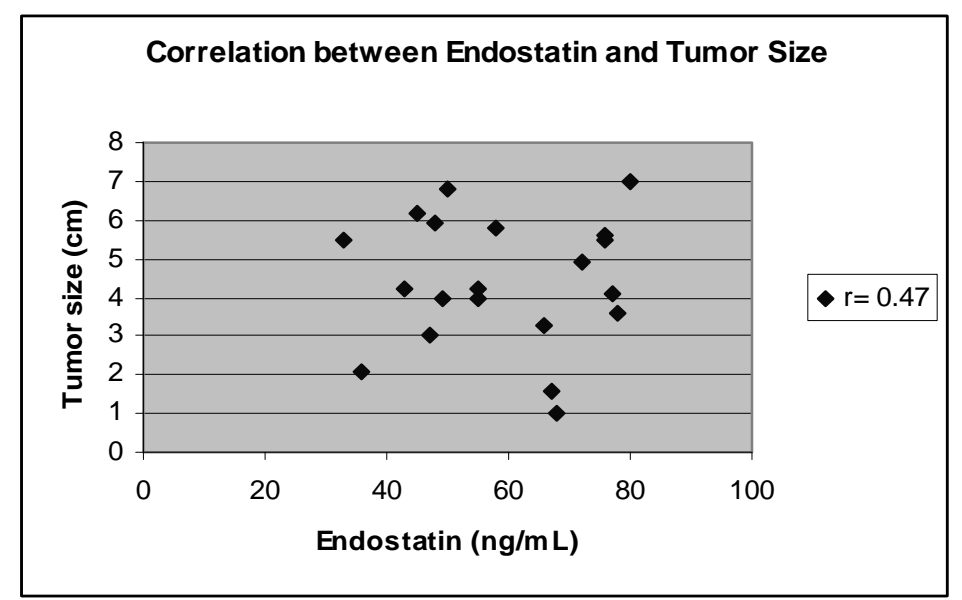

Fig. 5: Scatter plot showing the correlation between preoperative serum endostatin and tumor size in localized CRC patients.

Association between preoperative endostatin and VEGF levels and burden of disease:

Table 6: Correlation between serum levels of VEGF and endostatin with tumor burden in patients with localized colorectal cancer before resection of the primary tumor.

\begin{tabular}{l|cccc}
\hline & $\begin{array}{c}\text { Tumor } \\
\text { size }\end{array}$ & Tumor grade & $\begin{array}{c}\text { Lymph node } \\
\text { metastases }\end{array}$ & Recurrence \\
\hline VEGF $(\mathrm{pg} / \mathrm{mL})$ & $\mathrm{r}=0.42$ & $\mathrm{r}=0.58$ & $\mathrm{r}=0.67$ & $\mathrm{r}=0.48$ \\
& $\mathrm{P}<0.05$ & $\mathrm{P}<0.01$ & $\mathrm{P}<0.01$ & $\mathrm{P}<0.05$ \\
Endostatin $(\mathrm{ng} / \mathrm{mL})$ & $\mathrm{r}=0.47$ & $\mathrm{r}=0.49$ & $\mathrm{r}=0.059$ & $\mathrm{r}=0.6$ \\
& $\mathrm{P}<0.05$ & $\mathrm{P}<0.05$ & $\mathrm{P}<0.01$ & $\mathrm{P}<0.01$ \\
\hline
\end{tabular}

* VEGF: Vascular endothelial growth factor.

$* P<0.05$ : significant.

Tumor burden $=$ tumor size $(\mathrm{cm})$, tumor grade $(\mathrm{T} 1, \mathrm{~T} 2, \mathrm{~T} 3)$, number of lymph node metastases and subsequent recurrence. 
Table 7: Serum levels of VEGF and endostatin in patients with grade 2 and grade 3 (T2, T3) tumors.

\begin{tabular}{|l|c|c|c|}
\hline & $\begin{array}{c}\text { Grade 2 (T2) } \\
\text { patients (n=10) }\end{array}$ & $\begin{array}{c}\text { Grade 3 (T3) } \\
\text { patients (n=10) }\end{array}$ & P value \\
\hline $\begin{array}{l}\text { VEGF } \\
(\mathrm{pg} / \mathrm{mL})\end{array}$ & $270 \pm 138.0$ & $463 \pm 74.3$ & $\mathrm{P}<0.001$ \\
\hline $\begin{array}{l}\text { Serum Endostatin } \\
(\mathrm{ng} / \mathrm{mL})\end{array}$ & $49.7 \pm 10.9$ & $68.2 \pm 11.4$ & $\mathrm{P}<0.001$ \\
\hline
\end{tabular}

* VEGF: Vascular endothelial growth factor.

* $P<0.05$ : significant.

Table 8: Serum levels of VEGF and endostatin in patients with and without recurrence.

\begin{tabular}{|l|c|c|c|}
\hline & $\begin{array}{c}\text { Patients with } \\
\text { recurrence (n=4) }\end{array}$ & $\begin{array}{c}\text { Patients without } \\
\text { recurrence (n=15) }\end{array}$ & P value \\
\hline VEGF (pg/mL) & $508.0 \pm 78.3$ & $300.0 \pm 114.0$ & $\mathrm{P}<0.001$ \\
\hline Serum Endostatin $(\mathrm{ng} / \mathrm{mL})$ & $73.0 \pm 9.1$ & $52.0 \pm 11.3$ & $\mathrm{P}<0.001$ \\
\hline
\end{tabular}

* VEGF : Vascular endothelial growth factor.

$* P<0.05$ : significant.

N.B.: These results cannot be statistically relied on due to the low number of localized CRC patients with recurrence after surgical resection.

Preoperative levels of circulating VEGF and endostatin were analyzed in relation to tumor size (Fig. 5), tumor grade (T1, T2, T3), lymph node metastases and subsequent recurrence (Table 6). High preoperative VEGF and endostatin levels were strongly associated with the previous tumor burden (Table 6). Also, serum VEGF and endostatin mean levels were significantly higher in patients with grade 3 (T3) $(463 \pm 74.3 \mathrm{pg} / \mathrm{mL}$; $68.2 \pm 11.4 \mathrm{ng} / \mathrm{mL}$ respectively) versus patients with grade 2 (T2) $(270 \pm 138$ $\mathrm{pg} / \mathrm{mL} ; \quad 49.7 \pm 10.9 \quad \mathrm{ng} / \mathrm{mL}$ respectively, $\mathrm{P}<0.001$ for each) (Table 7). Furthermore, there were significant differences in both serum VEGF and endostatin levels between patients with subsequent recurrence $(508 \pm 78.3 \mathrm{pg} / \mathrm{mL} ; 73 \pm 9.1 \mathrm{ng} / \mathrm{mL}$ respectively) versus those without recurrence $(300 \pm 114 \mathrm{pg} / \mathrm{mL} ; 52$ $\pm 11.3 \mathrm{ng} / \mathrm{mL}$ respectively; $\mathrm{P}<0.001$ for each) (Table 8). 
Table 9: Number and volume of hepatic metastases in patients with elevated and patients without elevated serum endostatin levels.

\begin{tabular}{|l|l|l|l|}
\hline & $\begin{array}{c}\text { Patients with } \\
\text { elevated endostatin } \\
\text { level (9 cases) }\end{array}$ & $\begin{array}{c}\text { Patients without } \\
\text { elevated endostatin } \\
\text { level (7 cases) }\end{array}$ & P value \\
\hline Serum Endostatin $(\mathrm{ng} / \mathrm{mL})$ & $77.6 \pm 14.4$ & $43.8 \pm 2.8$ & $\mathrm{P}<0.001$ \\
\hline Number of metastases & $9.8 \pm 7.2$ & $2.4 \pm 1.5$ & $\mathrm{P}<0.005$ \\
\hline Volume of metastases(mL) & $254.6 \pm 107.5$ & $70.4 \pm 24.8$ & $\mathrm{P}<0.001$ \\
\hline
\end{tabular}

-Patients with elevated endostatin levels are those with serum endostatin $>54.6 \mathrm{ng} / \mathrm{mL}$

-Patients without elevated endostatin levels are those with serum endostatin $<54.6 \mathrm{ng} / \mathrm{mL}$

$* P<0.05$ : significant.

The mean number of hepatic metastases among patients with elevated preoperative endostatin levels $(9.8 \pm 7.2)$ was significantly higher than among those without elevated levels $(2.4 \pm 1.5: \mathrm{P}<0.005)$. Similarly, the mean total volume of hepatic metastases among patients with elevated preoperative endostatin levels $(254.6 \pm 107.5 \mathrm{~mL})$ was significantly higher than among those without elevated levels (70.4 \pm 24.8 $\mathrm{mL}: \mathrm{P}<0.001)$ (Table 9). Significant positive correlation was detected between endostatin levels and the number of hepatic metastases $(\mathrm{r}=0.5$ : $\mathrm{P}<0.05$ ) (Table 9). Also, there was significant positive correlation between endostatin levels and total volume of hepatic metastases $(\mathrm{r}=$ 0.54: $\mathrm{P}<0.05)$. There was no significant correlation between the estimated tumor burden and levels of VEGF.

\section{DISCUSSION}

Solid tumors rely on angiogenesis for sustained growth and produce cytokines that induce neovascularization ${ }^{\mathbf{( 2 1 )}}$. It is interesting that tumors can, also, produce antiangiogenic cytokines, (22) an observation hypothesized to be associated with the clinical observation that resection of primary human tumors may lead to growth of distant metastatic disease. This phenomenon has been demonstrated in murine models ${ }^{(23)}$. Because inhibiting tumor angiogenesis has become an attractive strategy for treating cancer patients, identifying the presence of circulating inhibitors of angiogenesis in humans with cancer might shed light on the role of these endogenous mediators in humans and suggest novel means to enhance their production or antitumor effects.

In the present study, serum levels of VEGF and endostatin levels were significantly higher in all patients with CRC than in the healthy controls. When compared according to tumor stage, the distant metastatic group had significantly greater levels of serum VEGF and endostatin than the localized invasive group (without distant metastasis). There was a significant positive correlation between preoperative endostatin and VEGF levels in all cancer patients. 
Consistent with the current results, Tien et al., ${ }^{(24)}$ reported significantly higher VEGF and endostatin serum levels in patients with superficial or invasive CRC compared to healthy controls. Feldman et al., ${ }^{(25)}$ reported that plasma endostatin levels are elevated in CRC patients with liver metastases. Guenther et al., (26) reported that in $\mathrm{CRC}$ and their liver metastases, high levels of collagen XVIII transcripts were observed in endothelial cells and fibroblasts/myofibroblasts.

Because hepatic metastatic disease represents the major cause of morbidity and mortality in patients with colon cancer, and because the liver is rich in collagen XVIII, the parent protein of endostatin ${ }^{(27)}$, plasma endostatin levels in colorectal cancer patients with liver metastases were prospectively analyzed. Several proteases have been demonstrated to cleave endostatin from collagen XVIII, including elastase $\mathrm{e}^{(\mathbf{2 8})}$ and cathepsin $\mathrm{L}^{(29)}$. Musso et al., ${ }^{(30)}$ reported that the increased global expression of the endogenous endostatin precursor, collagen XVIII, in hepatic metastases of CRC results from the combined expression profiles of tumor cells, and nontumor hepatocytes at the advancing edge of the tumor.

With the exception of the original hemangioendothelioma cell line from which murine endostatin was first isolated, tumor cell lines have not been shown to produce endostatin ${ }^{(31)}$. Therefore, it is reasonable to hypothesize that endostatin production in humans occurs as a result of extracellular cleavage of collagen XVIII. Because the liver is particularly rich in collagen XVIII, elaboration of these proteases by tumor would be expected to generate endostatin. It is interesting to note that in a study of patients with hepatocellular carcinoma Yamagata et al., ${ }^{(32)}$ found circulating endostatin levels similar to those of controls. Therefore, the production of proteases capable of cleaving endostatin from collagen XVIII may vary between tumor histologies and merits further study.

The inter-relationship between the antiangiogenic factor endostatin and the angiogenic factor VEGF, which was first noted in patients with clear-cell renal cancer ${ }^{(25)}$, could be explained as a part of a dynamic equilibrium process. Invasive tumors secrete VEGF and multiple collagenases, including MMPs, that facilitate digestion of the extracellular matrix and basement membrane, allowing the tumor cell access to the circulation. VEGF, in addition to promoting endothelial cell proliferation, also, induced the release of multiple collagenases and other proteases from endothelial cells ${ }^{(33)}$. Simultaneously, these collagenases (eg, MMP-9, MMP-3) might cleave endostatin from collagen XVIII. It is, also, possible that elevated endostatin levels represent a direct response to elevated VEGF levels ${ }^{(34)}$. Hypoxia, for example, is often present in tumors and has been shown to induce expression of both VEGF $^{(35)}$ and cathepsin $\mathrm{L}^{(\mathbf{3 6})}$. In turn, endostatin blocks angiogenesis by decreasing VEGF expression and inducing apoptosis in cancer cells ${ }^{(37)}$. Binding of endostatin to its receptor-like molecules present on the surface of 
endothelial cells transfers intracellular signals to block VEGF-mediated endothelial cell signaling. Endostatin, also, interferes with the interaction between VEGF and its receptor, thus again blocking the VEGF-mediated signaling events that result in the blocking of VEGF-induced proliferation and migration of endothelial cells.

The ability of endogenous human endostatin to inhibit angiogenesis is unknown at present ${ }^{(38)}$. Thus, it is not clear whether endogenous endostatin represents part of a defense mechanism to protect the host from tumor angiogenesis or simply is a byproduct of proteases secreted by the tumor. In either case, endostatin production might be expected to be increased in patients with more aggressive disease. In the current study preoperative levels of circulating VEGF and endostatin were analyzed in relation to tumor size, tumor grade, lymph node metastases and subsequent recurrence. High preoperative VEGF and endostatin levels were strongly associated with the previous tumor burden (Table 6). Also, it was found that the elevated endostatin levels, found in this work, were associated with greater tumor burden in colorectal cancer patients with liver metastases. Patients with elevated endostatin levels had significantly more metastatic lesions and greater hepatic disease burden and were less likely to be deemed eligible for surgical treatment. Similarly, Feldman et al. ${ }^{(39)}$ demonstrated that in patients with soft-tissue sarcomas, elevated preoperative endostatin levels were more likely to have recurring tumors after resection than patients without elevated endostatin levels.

The present study, also, showed that serum endostatin and VEGF levels in localized invasive group were decreased significantly after resection of the primary tumor (table $5)$. These results are coordinated with those reported by Charlotte et al., ${ }^{(40)}$ who demonstrated that the increased metabolic activity in liver metastasis after removal of primary colorectal carcinoma coincided with a decrease in antiangiogenic factor levels. Also, Fujisaki et al., ${ }^{(41)}$ found that circulating levels of VEGF decreased after resection of primary colorectal cancers. After resection of the tumor, levels of circulating angiogenic and antiangiogenic factors would reflect a balance between the loss of the tumor stimulus and the addition of the regeneration stimulus. Multiple factors might be responsible for the decrease of endostatin after surgery. Removal of the tumor might be one factor for both VEGF and endostatin decrease. Surgical trauma with subsequent release of various proteolytic enzymes involved in healing of the wound may degrade endostatin. That postoperative endostatin decrease further substantiates the idea that a tumor may produce angiogenic inhibitors, suppressing their metastases at distance.

From the current results, it could be suggested that to prevent accelerated vascularization and growth of distant (micro)metastases, the primary tumor should not be removed. However, more than $50 \%$ of patients with primary colorectal malignancies who present without 
metastasis are cured by surgery ${ }^{(42)}$, indicating that surgical removal of the primary tumor is mandatory and not just optional. Furthermore, the risk of metastasis is proportional to the number of circulating metastatic cells that originate from primary tumor ${ }^{(43)}$. Obviously, resection will remove the source of these cells. These results may indicate that administration of antiangiogenic compounds after the surgical removal of a primary tumor may be an interesting approach to inhibit outgrowth of distant (micro)metastases. In animal models, substantial evidence has been presented that vascularization and subsequent growth of distant metastases could be inhibited by systemic administration of the angiogenesis inhibitors angiostatin and endostatin ${ }^{(23)}$. In humans, that approach may be helpful in preventing the outgrowth of liver metastases, a major cause of mortality in colorectal carcinoma patients.

Because of the small number of patients recruited in the current study and the wide range of circulating endostatin levels observed in healthy controls, a much larger analysis would be required to assess the feasibility of using circulating endostatin levels as a tumor marker of progression or recurrence.

\section{Conclusion:}

The current results denote that serum levels of endostatin, and VEGF were elevated and positively correlated in patients with CRC patients. The elevation was associated with the disease stage, burden and recurrence of CRC. Thus, elevation of serum levels of endostatin, and VEGF might be considered as indicators of tumor invasion and metastasis in the future demonstrating the prognostic utility of measuring angiogenic and antiangiogenic factors before resection of colorectal cancer. However, larger scale analysis is required to assess the feasibility of using circulating VEGF, and endostatin levels as tumor markers of recurrence or progression in patients with CRC. Understanding the role of endogenous endostatin in patients with colorectal cancer might lead to novel treatment strategies to inhibit tumor angiogenesis.

\section{REFERENCES}

1. Potter, J.D.; Slattery, M.L.; Bostick, R.M.; and Gapstur, S.M. (1993): Colon cancer: a review of the epidemiology. Epidemiol. Rev., 15: 499-545

2. Vernava, A.M.; Longo, W.E.; Virgo, K.S.; et al. (1994): Current follow-up strategies after resection of colon cancer. Results of a survey of members of the American Society of Colon and Rectal Surgeons. Dis. Colon Rectum 37:573-583

3. Folkman, J. and D'amore, P. A. (1996): Blood vessel formation: what is its molecular basis. Cell 87: 1153-1155.

4. Folkman, J. and Shing, $Y$. (1999): Angiogenesis. J. Biol. Chem., 267: 10931-10934.

5. Hanahan, D.; and Folkman, J. (1996): Patterns and emerging mechanisms of the angiogenic switch during tumorigenesis. Cell, 86: 353-364.

6. Folkman, J.(2000): Role of angiogenesis in tumor growth and 
metastasis. Semin. Oncol., 29(Suppl. 16): 15-18.

7. Yoshiji, H.; Kuriyama, S.; Hicklin, D. J.; et al. (1999): $\mathrm{KDR} / \mathrm{FIk}-1$ is a major regulator of vascular endothelial growth factor-induced tumor development and angiogenesis in murine hepatocellular carcinoma cells. Hepatology 30: 1179-1186.

8. Bruns, C. J.; Lin, W.; Davis, D. W.; et al. (2000): Vascular endothelial growth factor is an in vivo survival factor for tumor endothelium in a murine model of colorectal carcinoma liver metastases. Cancer 89: 488-499.

9. Ferrara N. (2002): Role of vascular endothelial growth factor in physiologic and pathologic angiogenesis: therapeutic implications. Semin. Oncol., 29(Suppl. 16): 10-14.

10. Laintinen, M.; Ristimaki, A.; Honkasalo, M.; et al. (1997): Differential hormonal regulation of VEGFs (VEGF, VEGF-B and VEGF-C) messenger ribonucleic acid levels in cultured human granulose- luteal cells. Endocrinology 138: 4748-4752.

11. O'reilly, M. S.; Boehm, T.; Shing, Y.; et al. (1997): Endostatin: an endogenous inhibitor of angiogenesis and tumor growth. Cell 88: 277-285.

12. Kerbel, R. and Folkman, J.(2002): Clinical translation of angiogenesis inhibitors. Nat. Rev. Cancer 2: 727-739.

13. Dhanabal, M.; Ramchandran, R.; Waterman, M. J.; et al. (1999): Endostatin induces endothelial cell apoptosis. J. Biol. Chem., 274: 11721-11726.
14. Dixelius, J.; Cross, M.; Matsumoto, T.; et al. (2002): Endostatin regulates endothelial cell adhesion and cytoskeletal organization. Cancer Res., 62: 1944-1947.

15. Thomas, J. P.; Arzoomanian, R. Z.; Alberti, D.; et al. (2003): Phase I pharmacokinetic and pharmacodynamic study of recombinant human endostatin in patients with advanced solid tumors. J. Clin. Oncol., 21: 223231.

16. American Joint Committee Updating TNM classification of the cancer, In Manual for staging of cancer (1988) : Beahrs, O.H.; Hensen, D.E.; Hutter, R.V.P.; and Meyer, M.H., Ed.; J.B. Lippincott Company, Philadelphia P.193.

17. Mostofi, F.K.; Sobin, L.H.; and Torloni, H. (1973): Histological typing of tumors. International Histological Classfication of Tumors, No:10 World Health Organization, Geneva..

18. Korzeniewska, M., Kolomecki, K.; Naze, M.; et al. (2005): Assessment of pro- and antiangiogenic factors, blood serum concentrations in patients with hormonal inactive adrenal tumors. Endokrynol. Pol., 56(1): 39-44.

19. Wrobel, T.; Mazur, G.; Kapelko, K., and Kuliczkowski, K. (2005): Endostatin serum level in acute myeloid leukemia. Neoplasma 52(2): 182-184.

20. Knapp, R.; and Miller, $M$. (1992): Clinical epidemiology and 
Horwall publishing

Co. Pennsylvania .

21. Desai, S.B.; and Libutti, S.K. (1999): Tumor angiogenesis and endothelial cell modulatory factors. J. Immunother., 22: 186211.

22. Westphal, J.R.; Van't Hullenaar, R.; Geurts-Moespot, A.; et al. (2000): Angiostatin generation by human tumor cell lines: involvement of plasminogen activators. Int. J. Cancer 86; 760-7.

23. Holmgren, L.; O'Reilly, M.S.and Folkman, J. (1995): Dormancy of micrometastases: balanced proliferation and apoptosis in the presence of angiogenesis suppression. Nat. Med., 1: 149-53.

24. Tien, Y.W.; Chang, K.J.; Chiu, Y.F.; et al. (2006): Comparison of angiogenic factor levels in tumor drainage and peripheral venous blood from colorectal cancer patients. Ann. Surg. Oncol., 13:1357-63.

25. Feldman, A.L.; Alexander, H.R. Jr.; Bartlett, D.L.; et al. (2001): A prospective analysis of plasma endostatin levels in colorectal cancer patients with liver metastases. Ann. Surg. Oncol., 8: 741-5.

26. Guenther, U.; Herbst, H.; Bauer, M.; et al. (2001): Collagen type XVIII/endostatin is differentially expressed in primary and metastatic colorectal cancers and ovarian carcinomas. Br. J. Cancer 85: 1540-5.

27. Musso, O.; Rehn, M.; Saarela, J.; et al. (1998): Collagen XVIII is localized in sinusoids and basement membrane zones and expressed by hepatocytes and activated stellate cells in fibrotic human liver. Hepatology 28: 98107.

28. Wen, W.; Moses, M.A.; Wiedershain, D.; et al.(1999): The generation of endostatin is mediated by elastase. Cancer Res., 59: 6052-6.

29. Felbor, U.; Dreier, L.; Bryant, R.A.; et al. (2000): Secreted cathepsin L generates endostatin from collagen XVIII. EMBO J., 19: 1187-94.

30. Musso, O.; Theret, N.; Heljasvaara, R.; et al. (2001): Tumor hepatocytes and basement membrane-producing cells specifically express two different forms of the endostatin precursor, collagen XVIII, in human liver cancers. Hepatology 33: 868-76.

31. O'Reilly, M.S.; Boehm, T.; Shing, Y.; et al.(1997): Endostatin: an endogenous inhibitor of angiogenesis and tumor growth. Cell 88: 277-85

32. Yamagata, M.; Shiratori, Y.; Dan, Y.; et al. (2000): Serum endostatin levels in patients with hepatocellular carcinoma. Ann. Oncol., 11: 761-3.

33. Zucker, S.; Mirza, H.; Conner, C. E.; et al. (1998): Vascular endothelial growth factor induces tissue factor and matrix metalloproteinase production in endothelial cells: conversion of prothrombin to thrombin results in progelatinase A activation and cell proliferation. Int. J. Cancer 75: 780-786. 
34. Feldman, A.L.; Tamarkin, L.; Paciotti, G.F.; et al. (2000): Serum endostatin levels are elevated and correlate with serum vascular endothelial growth factor levels in patients with stage IV clear cell renal cancer. Clin. Cancer Res., 6: 4628-34

35. Shweiki, D.; Itin, A.; Soffer, D.; and Keshet, E.(1992): Vascular endothelial growth factor induced by hypoxia may mediate hypoxiainitiated angiogenesis. Nature 359: 843-5.

36. Cuvier, C.; Jang, A. and Hill, R.P.(1997): Exposure to hypoxia, glucose starvation and acidosis: effect on invasive capacity of murine tumor cells and correlation with cathepsin $(\mathrm{L}+\mathrm{B})$ secretion. Clin. Exp. Metastasis 15: 19-25.

37. Du, Z. and Hou, S. (2003): The anti-angiogenic activity of human endostatin inhibits bladder cancer growth and its mechanism. $\underline{\mathrm{J}}$. Urol., 170: 2000-2003.

38. Standker, L.; Schrader, M.; Kanse, S.M.; et al. (1997): Isolation and characterization of the circulating form of human endostatin. FEBS (Lett.) 420: 129-33
39. Feldman, A.L.; Pak, H.; Yang, J.C.; et al. (2001): Serum endostatin levels are elevated in patients with soft tissue sarcoma. Cancer 91: 1525-9

40. Charlotte, F. J. M. P.; Lioe-Fee, D. G.; Johan, R. W.; et al.(2005): Decrease in circulating anti-angiogenic factors (angiostatin and endostatin) after surgical removal of primary colorectal carcinoma coincides with increased metabolic activity of liver metastases. Surgery137:246-9.

41. Fujisaki, K.; Mitsuyama, K.; Toyonaga, A.; et al. (1998): Circulating vascular endothelial growth factor in patients with colorectal cancer. Am. J . Gastroenterol., 93: 249-52.

42. Abulafi, A. M. and Williams, N.S. (1994): Local recurrence of colorectal cancer: the problem, mechanisms, management and adjuvant therapy. Br. J. Surg., 81: 7-19.

43. Fidler, I.J.; Balch, and C.M. (1987): The biology of cancer metastasis and implications for therapy. Curr. Probl. Surg., 24: 129-209. 


\section{عملية تكوين الاوعيه الدمويه الجديده و مقاومتها فى مرضى سرطان القولون}

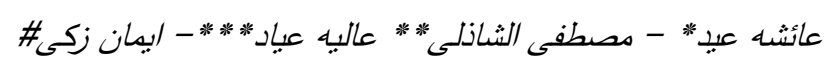

أقسام الكيمياء الحيويه الطبيه*-- الجراحه***- الأمراض الباطنه **** - الأشعه\#- كليه الطب-

معهد الأورام القومى \# - جامعه القاهرة

أجرى هذا البحث لاراسة منشطات عملية تكوين الاوعيه الدمويه الجديده متمنله فى عامل النمو للغشاء

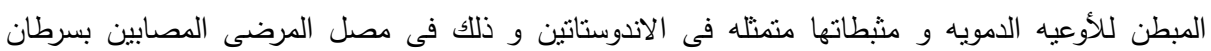

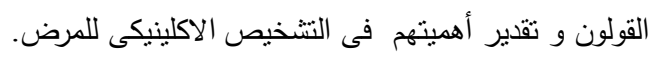

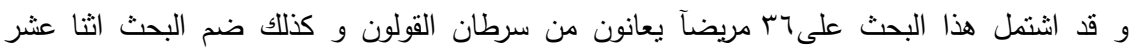
شخصا من الأصحاء كمجموعه ضابطه. و قد تم قياس كل من عامل النمو للغثاء المبطن للأوعبه الدمويه و الاندوستانين.

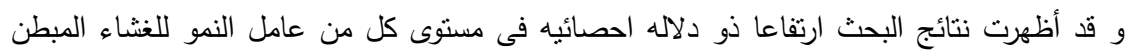

للأوعيه الدمويه و الاندوستاتين فى مصل المرضى المصابين بسرطان القولون مقارنة بالمجموعه الضابطه. وقد نم تقسيم المرضى تبعا لمرحلة المرض اما مرحله بدون اورام ثانويه أو مرحله متقدمه مصحوبه بأورام ثانويه

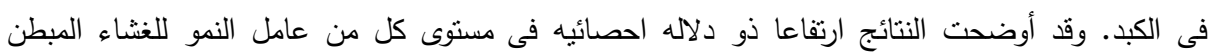

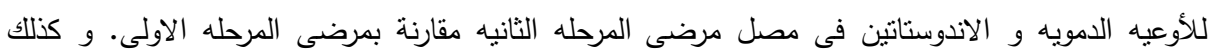
ارتفاعا ذو دلاله احصائيه فى كل من المجموعنين السابقتين مقارنة بالمجموعه الضابطه.

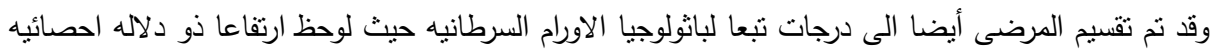

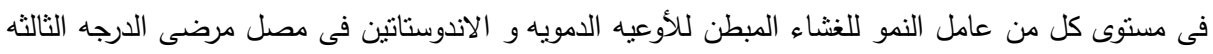

مقارنه بالدرجه الاولى و الثانيه ولكن لا يوجد اختلاف ذو دلاله احصائيه بين المجموعتين الاولى و الثانيه.

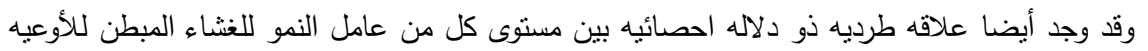

الدمويه و الاندوستانين فى مصل المرضى المصابين بسرطان القولون.

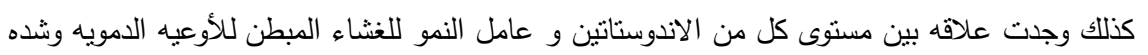
المرض فى المرضى المصابين بسرطان القولون حيث وجدت علاقه طرديه ذو دلاله احصائيه بين مستوى

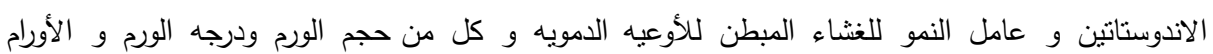
المصاحبه فى الغدد الليمفاويه و ارتجاع الورم. أيضا أظهرت النتائج وجود علاقه بين مستوى الاندوستاتين و شده المرض في الفى المرضى المصابين بسرطان القولون المصحوب بأورام ثانويه فى الكبد حيث وجدت علاقه طرديه ذو دلاله احصائيه بين مستوى لإنى

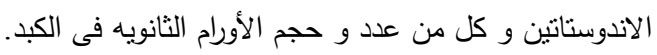

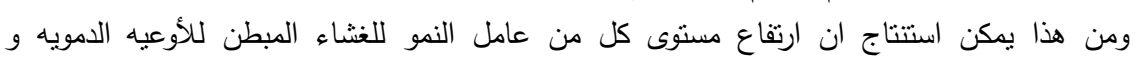
الاندوستانين فى مصل المرضى المصابين بسرطان القولون مرتبط بمراحل و تدرج ورم القولون ويمكن استتناج

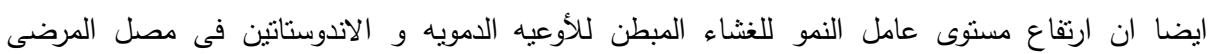

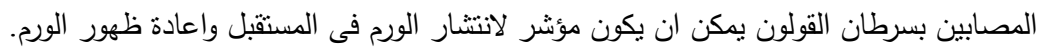

